\title{
Performing the Body in Filipino Narratives \\ The Manananggal (Viscera Sucker) in Colonial Literature
}

\section{- Hope Sabanpan-Yu \\ University of San Carlos, Cebu City}

\begin{abstract}
In narratives of the manananggal in Filipino literature, women self-segment and feed on human fetuses and internal organs to sustain themselves. The manananggal's body bisects, leaving the lower half of it somewhere safe and the upper half flying to find sustenance. Using the stories as examples, this paper seeks to explore the profound transformation whereby the belief in the cannibalistic feature of the viscera sucker is not only an inversion by the Spanish friars to discredit the babaylan of her crucial role in Filipino society but as also arising from a sense of women's sexual and maternal agency surrounding their bodies. This paper seeks to problematize traditional readings and to re-think traditional attitudes to the body. It examines how and why female transgressive desire finds its ideal expression through the manananggal in Filipino literature.
\end{abstract}

\section{Keywords}

sexuality, body, Manananggal, Filipino literature 


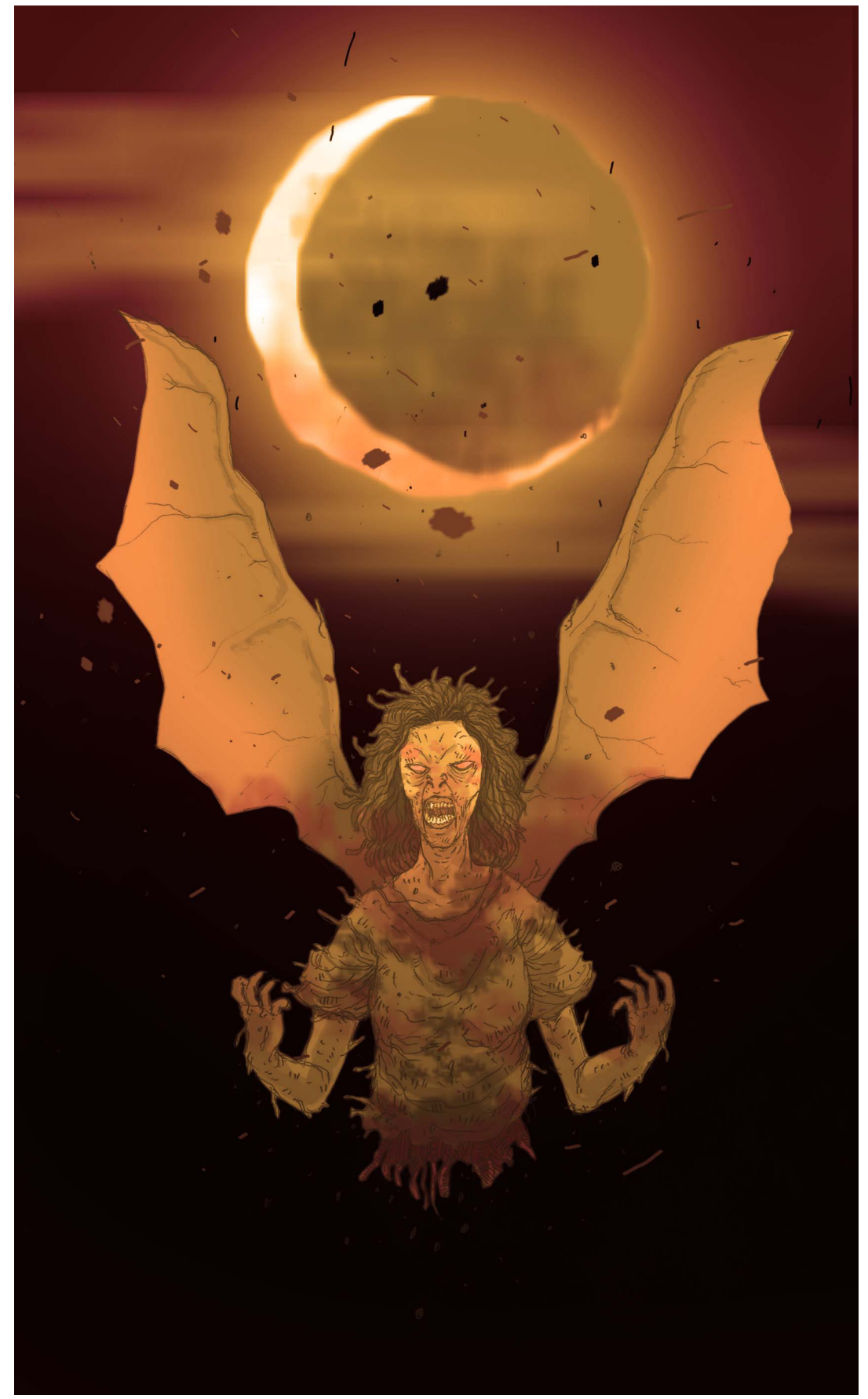

An Illustration of a Manananggal (Credits to John Michael Cadena) 
There is an anecdote entitled “The Witch of Tawas" in Damiana Eugenio's The Legends about a manananggal (viscera sucker). The story has it that one night when everything was very quiet and everyone was already asleep, Mang Tano, an old man in the place, was awakened by a strange sound like the flapping of wings. Mang Tano got his bolo and opened the door to go down. He saw a strange figure, half-woman and half-bird, with enormous wings. When he was just about to hit her with the bolo, she flew swiftly away and disappeared. The strange figure was believed to be a manananggal.

Everyone suspected that it must be that old gray-haired woman of the village about seventy years old, whose identity was uncertain. She was unknown to the barrio folks because she was seldom seen going around at daytime. On another evening, while Aling Marta was mending some clothes, she heard the flapping of wings on the rooftop. Then Aling Marta noticed a threadlike material suspended from the ceiling. Instinctively she got her scissors and cut it off. To her amazement a sudden cry of pain was heard, followed by the sound of flapping of wings. Upon learning of this, Aling Marta's husband got his bolo and gathered some neighbors to go with him to the old woman's house. They found the old woman bleeding profusely in her mouth.

I use this narrative as a model for tracing the shift from the belief in the manananggal as a folkloric figure in the ancient times to the subordination of the babaylan (priestess) - that is to say, of the performative body over the corporeal body in the tales of colonial Philippines. I argue that this reflective transformation is entangled in the complex and shifting relationships between the body and female sexuality and between erotic desire and power that came to be expressed in the period.

It would not be an overstatement to say that many areas of intellectual study to date see the body as central to their interests. Feminist scholars view the female body as being key to our understanding of how power works in society. The different meanings that have come to be associated to childbirth and menstruation, for instance, that are experienced through the body, reveal the construction of gender and sexuality. Although gender may be seen as "performative" in poststructuralist readings, ${ }^{2}$ it is also accepted that 
the body is heterogeneous in nature and produced in many different ways in different cultural contexts. This paper however does not intend to deal in any sense with the "real" body. Instead, it concentrates on the ways in which the female body came to be envisaged in the literary and historical texts of early Philippines, how it was brought into being through a particular discourse.

Herminia Meñez describes the manananggal as seductively beautiful with long hair and a fair complexion during the day: ${ }^{3}$

By night, she discards her lower torso, hiding it under the sheets, in a closet, or among a patch of banana trees. Having converted her arms into wings by anointing her armpits with a noxious oil and being propelled by her now stiffened hair, she takes to the air, alights on a roof, and thrusts her long tubular tongue through the palm shingles to extract the viscera of her sleeping victims through her mouth, nostrils, ears, anus, navel, or genitalia. She stalks tuberculars and pregnant women because she is addicted especially to phlegm and fetuses, as well as to human liver and blood. After feasting, she returns home to rejoin her lower trunk before daybreak. However, if someone, usually her new husband, rubs any or all of the following-ashes, salt, vinegar, lemon juice, garlic, ginger, pep-per, and other spices-on her discarded part, reattachment is impossible, and the viscera-sucker dies fragmented. ${ }^{4}$

The manananggal is the most virulent type of asuang that is popular in lowland Christian communities, especially in the Visayan and Bicol regions which were the first to be intensively "missionized" by the Spaniards from the early sixteenth to the late nineteenth century. ${ }^{5}$ Jean-Michel Sallmann in History of Women in the West explains:

The belief that women possessed evil, supernatural powers was an ancient one. In antiquity the strix was alleged to be a man-eating woman who flew through the air at night; there were reported sightings of such creatures in the Middle Ages and again in the sixteenth century. In the fifteenth century belief in the power of women to cast spells combined with the Satanic myth to give rise to that hybrid, demoniac witch. The demonological myth took shape in the context of medieval heresy. ${ }^{6}$ 
In many ways, the manananggal inspires the same fears as the other creatures of lower mythology since they force people to confront their own fears of mortality. Manananggals can also inspire the fear of contamination ${ }^{7}$ and because of their ability to kill, they call attention to the fear of death. Manananggals are a source of repulsion being awful and even perverse, but it may be considered a symbol of sexuality, however much this fact is disguised from view. Julia Kristeva's abjection helps to explain this exciting combination of fear and desire. ${ }^{8}$ The abject creates both a sense of disgust as something to be cast out, while at the same time evoking a desire to know and even possess the object that creates this deep disturbance. Although manananggal mythology has not changed much throughout the centuries, this paradox of being both attracted to and repelled by her continues and ultimately reflects upon the audience's own desires and fears rather than on the manananggal as symbolic on its own. She is not only portrayed as having a thirst for the unborn, but she is also shown as disrupting reproduction and traditional family structures by rendering men impotent, creating miscarriages in women, arousing men and prompting them to commit adultery under her spell.

Through the trope of the uncontained body, ideas of liberation, freedom and subversion permeate the manananggal stories. The manananggal engages in scary and transgressive behavior which challenges cultural borders of identity and contributes to the realignment and repositioning of cultural concepts. Meñez discussed the manananggal as a case being developed by Spanish religious leaders to co-opt the traditional leadership role of women, or what she calls a "process of disenfranchising the most powerful Filipino women and a politics of gender that has deep roots in the Spanish conquest of the Philippines."

Greg Bankoff's article ${ }^{10}$ about the interesting case of Seberina Candelaria ${ }^{11}$ in the early nineteenth century illuminates the power structure and dissent in the narrative of supernatural belief in the rural Philippine community, and makes for a case of what Meñez points out. Early versions of precolonial Philippines indicate that the various peoples of Luzon and the Visayas were animists who worshipped the spirits of the natural world and those 
of their ancestors. They also endeavored to appease a mass of malevolent spirits. Ceremonies were celebrated mostly by women known as catalonans ${ }^{12}$ or babaylanes ${ }^{13}$ in private homes or at feasts by the host's home. During these ceremonies, the priestess often entered into a trance where her body would become possessed by the spirit being evoked or placated. Sometimes her actions would turn violent, and she would hurl to the ground and foam at the mouth, and her hair would stand on end. ${ }^{14}$ In these situations the priestess communicated with the participants and interpreted signs and omens.

Apart from divination and auguries usually performed on animal entrails, the priestesses were also consulted as physicians. Evidently, many had extensive knowledge of herbs whose properties were used medicinally to cure disease which, no doubt, contributed to their status. But their station in indigenous society remains more difficult to gauge. Spanish missionary sources attempt to decry their influence: Fr. Colin contending that 'they were not honoured or esteemed' but considered 'an idle lot who lived by the sweat of others.' Pedro Careen, on the other hand, while dismissing the priestesses as 'a band of worthless women,' goes on to deplore their 'tyrannical hold' upon the village 'by various means and plots compelling many to repair to them upon every occasion.' However, their function as intermediaries with the spirit world, often on behalf of the sick, combined with their medicinal skills, confirm the role of these women as shamans whose importance would be considerable especially within societies without highly developed superordinate forms of social control. ${ }^{15}$

Carolyn Brewer in Holy Confrontation: Religion, Gender and Sexuality in the Philippines, 1521-1685 writes that according to Jaime Veneracion, "it was the Spanish who labelled women 'suspected of being babaylans ... as witches (bruha)."16 But when the Spanish attitudes crossed cultural boundaries, the negative impact on the babaylan had sweeping results.

At the basis of this negative relabelling was the desire by the Spaniards to eliminate Animist religion and concomitantly any resistance to the introduction of Catholicism. Their actions resulted in the marginalization, and in some instances, the total extirpation of the entire cultural, social and religious practices of the indigenous peoples who came into contact with the missionaries.... In the Philippine setting, while the actual 'genocide' of ethnic groups did not occur, the introduction of Hispanic Catholicism was 
accompanied by an homogenization of the different cultures-to such an extent that the ways of the Animist ancestors were largely forgotten. In this process, the impact on women religious leaders was profound. ${ }^{17}$

It is no wonder then that Seberina Candelaria, a twenty-two-year-old illiterate woman from Obando, Bulacan, is arraigned before an ecclesiastical court accused of associating with the Devil. Seberina together with a duende (demon familiar) ${ }^{18}$ was able to determine the identity of thieves, the whereabouts of lost items, and other wonders during nightly assemblies held in the town of Obando. These gatherings attracted many people to bring money and other offerings so that they could ask questions of her and get responses to their questions about stray animals or lost items. ${ }^{19}$ Others asked if their loved ones were safe or had been jailed. There were indications that Seberina also acted as a healer. ${ }^{20}$

Studying the evidence collected during the trial provides an opportunity to get into the consciousness of someone who lived more than two centuries ago and see the world as Seberina did. She was followed one day while on her way home after prayers from Polo. She asked her pursuer why he was following a married woman like her and he made crude remarks that cast doubt on her marital status. They continued on the way as before, and when Seberina neared her mother-in-law's house the tree began to shake violently and other strange things started happening. Objects mysteriously moved, but there was no sign of the man. Some days later a small man appeared and offered her a golden rosary and a purse of money. When she refused the offer he threw sand into her eyes and called her mad. After this, he appeared mostly during sunset and told her his name was Isac and that he was a demon familiar. ${ }^{21}$ When Seberina returned to Obando, Isac followed and conversed with her frequently. He could answer any question she asked and when this news spread, people started coming to consult him. Soon Seberina was invited to homes and Isac went with her. However no one ever really saw him. They heard his voice but could not see him. All the gatherings took place after dark. 
Seberina is arrested and confined to the stocks in the town hall. Isac follows her even there. When Isac refuses to leave when Seberina requests to be left alone, she resorts to reciting the Creed and then mayhem breaks loose. Isac hurls a large piece of wood at her and he begins to lift the stocks. A guard arrives in time to save her. From that time on, Seberina never hears from Isac again. ${ }^{22}$

The testament of Seberina Candelaria provides insight into the world view of rural life in the Philippines at the beginning of a century of transition. Bankoff states that it raises "serious questions about the degree to which Christianity had displaced earlier beliefs after more than 200 years of friar evangelisation and mission in the archipelago." ${ }^{23}$ It is not surprising to find too that the babaylanes were blamed for the regular incidences of apostasy. Meñez analyzes Spanish chronicles ${ }^{24}$ written to show how Spanish friars dealt with these recalcitrant women who were seen as their rivals. Even with the prejudice shown in the accounts, the babaylanes come out as defenders of the indigenous faith. Meñez notes that

When Spanish missionaries attempted to enter a village in upland Northern Luzon, these shamans would congregate at the outskirts to prevent their entrance. They frightened local chiefs who had acquiesced to the foreigners by making "dire predictions and throwing fits." They also accompanied their warriors to battle to incite the men into fighting fury and to hurl invectives at their foreign enemies. ${ }^{25}$

For the Spanish priests of the time, the babaylans and the manananggals were of the same type. Propaganda against them was spiced up with the discourse of European Inquisitors and exorcists. ${ }^{26}$ The authorities were hostile to the preservation and practice of pre-Christian rites. Parishioners were encouraged to avoid these and denounce the babaylanes on pain of being punished severely. ${ }^{27}$ The power of the babaylan was gradually upturned into that of the manananggal. Meñez sketches for us this process:

In the majority of the narrative texts, her most striking quality is her propensity for human fetuses, internal organs, and bodily discharges. A common episode graphic-ally describes a self-segmenter attaching herself 
like a bat underneath the slatted bamboo floor awaiting the sputum and phlegm voided by the tubercular patient lying above. With her hollow tubular tongue, elongated thin as a thread when necessary, she drains the fetus out of the womb or, more dramatically, incises a pregnant woman's belly with her long fingernails to remove the infant. ${ }^{28}$

Further, Meñez adds that the manananggal also represents inversions of even more important Filipino values of family solidarity and sociality: "She has no regard for kinship since she is obliged to cannibalize one of her own family members as an essential step in her initiation as a witch. She detests social groups, preferring to live a marginal, secretive and lonely life." ${ }^{29}$

Spanish chronicles indicate how the friars contributed to the passing away of female priesthood. They denounced the babaylanes as primitive, unchaste women, practitioners of a fraudulent religion, and most of all, as priestesses of the devil. The priests burnt down their anitos ${ }^{30}$ and sacred groves in the drive to eliminate what in their view were "the two greatest sins-sexual license and alcoholic indulgence," which supposedly climaxed during shamanic rituals. ${ }^{31}$ The degree of zealous influence on the formulation of the manananggal as the reversal of the babaylan cannot be underscored enough. There were mass conversions and their success was such that the natives started to take their sick to church to be healed. ${ }^{32}$

Mass conversions by baptism did not eradicate the indigenous religions. More vigorous attacks were then launched against the shamans. If these leaders admonished their people not to abandon their deities, Spanish priests quickly countered with Masses and processions, as well as with blatant destruction of any signs of animist faith. Recalcitrant shamans were made to wear the Agnus Dei scapular; relapses were "cured" by confessionals and sermons.... [G]iven the fact that Spanish priests punished the natives with beatings for sexual excesses and other infractions such as going topless, for which women received fifty lashes, it is hard to believe that the priestesses escaped physical torture. Moreover, the chroniclers proudly report how with constant psychological harassment, even the most stubborn leader of "a band of worthless women" finally converted after relentless rites of exorcism. ${ }^{33}$ 
As babaylanes lost their official status, they increasingly became involved in rebellions and resistance movements. The babaylanes acted as spokesperson or conduit, communicating the will of the divine and attested heavenly approval of the cause. When she takes up this ritual role, the babaylan undermines the Christian hierarchy in two ways. First, under ordinary circumstances, women are excluded from any such rites, with only men in dominant positions. Second, her participation and support in the rebellion is itself seen as an attack on the established hierarchy since the Christian model demanded loyalty from everyone. Although never monolithic, the Christian model became the dominant organizing force in Philippine-Hispanic social structures. In these models, social relationships are organized according to a prescribed hierarchical system of loyalty and obligation. The frayle (friar) was literally the son of heaven and his relationship of obedience and piety served as a model for the loyalty of officials to the church and also for familial relationships encompassing the obedience of wife to husband, that of children to parents, younger siblings to older, and so on.

Where the babaylan was formerly held in esteem for her skills as a midwife, healer and prophet, as the asuang she now "drains the fetus out of the womb" and kills infants in her desire for flesh. This "opposition between life taking and life giving, between killing and birthing, is underscored by the self-segmenting process in which the reproductive half is left behind while the upper half is engaged in death-dealing activity." ${ }^{34}$

The narratives express a real tension in colonial Philippine society regarding women's roles in the community. Women in male-defined and male-dominant social systems are rarely as passive or as powerless as the societal ideal would demand. Feminist anthropological studies ${ }^{35}$ have described the structure of the colonial Philippine family from the woman's point of view. These studies suggest that supernatural beliefs about the danger to men of women's sexual activity, as well as literary images of asuang, are two expressions of the potential power that women actually had to disrupt men's lives and patrilineal lines. As Jeffrey Jerome Cohen notes, “[ $\mathrm{t}]$ he monstrous body is pure culture. A construct and a projection, the monster exists only to be read: the monstrum is etymologically 'that which reveals,' 'that which 
warns." 36 The manananggal certainly necessitates discussions of what such monstrosities are as they can serve as embodiment of moral dilemmas over such actions. The woman-bat hybrid figure is therefore a monstrous embodiment of both the fears of relatedness to the nocturnal creature as well as the uncertainties about the limitations of human perspectives.

But the manananggal can also give what Stacy Alaimo terms a "pleasurable sense of identification." ${ }^{37}$ In her study of monstrous natures in contemporary horror, she states that "[p] erhaps the horrific but pleasurable sense of the 'melting of corporeal boundaries'... can catalyze some sort of resistance to the desire to demarcate, discipline, and eradicate monstrous natures" (294). Here the manananggal can function as a necessary representation of a move beyond categorization and separation of woman from nature to a community of kinship with other animals, specifically the bat. In many cultures, though, the bat is associated with darkness, death, witchcraft and malevolence. This grapples with the human existential fears of isolation, independence and nonconformity. The fear of both disconnection and connection must be contended with, as the joining fear and desire confound the possibility for accepting and combining these stories of interrelatedness into notions of the self. When one considers oneself like a "bat" is to some extent embrace it and identify with it. This may be what people find both frightening as well as exciting about this way of thinking, as the limitations of the woman are transcended in the ability to escape surveillance, in non-generativity and in sustaining herself with fetuses taken from would-be mothers.

In conclusion, the folkloric manananggal's devouring can be read in several interconnected ways. First, it may reflect the fear of people of the unborn child being devoured and destroyed. Here it is the patriarchal structure that "others" the manananggal's "barrenness." She is to be feared because she feeds on the fertile woman's offspring. The manananggal does not have children. So if we are to read and consider the part of the manananggal, this devouring may be seen as a woman's fantasy of literally incorporating the baby. In this manner, the boundary between her and the baby disappears. She has the baby inside without having to carry her in the womb, without having to go through pregnancy. If the manananggal's fetus-eating is related to iden- 
tification by incorporation of the other's body, she is not complying with the Other but with her own perception of the Other. The patriarchal structure will shun such a feminist move as she does not subscribe to the norm of the ideal woman, specifically one who will mother. The manananggal defies the very attempt to extricate the maternal subjectivity, as if to say that there is no such thing as a mother.

Because the manananggal provides such a mesmerizing locus for thinking about the hybrid creature discussed above, she can become a crucial figure in the shift in thinking from folk villain-ness to a more fluid idea of woman. Her hybridity necessitates that we rethink not only the bounds of the human (woman) and accept her interrelatedness with the qualities of the nocturnal mammal. The best gauge for this shift is more likely to be found in popular culture, as the audience to be pleased is the wider population, and so the themes with which they are attached to will be in what interests the public most. Pop culture can question the status quo and push cultural perceptions in new directions. It is a good place to endorse these changes as it approaches the public on common ground-the comics or in film or in a book. For instance, in the movie Ang Manananggal sa Unit 23B (The VisceraSucker in Unit 23B), Jewel (the manananggal) preys on different solitary alpha-males and assembles their bodies as victims of drug pusher rub-outs that have cardboard signs that reflect the current plight of society's vicious criminals. From here, she can push the viewers a step farther into unknown territory indicating the public's need to respond to developments in society. Without this visualization, we are not likely to make the radical shift in our thinking of human (woman) that is necessary. This woman-bat vision of boundary-blurring forces us to reconsider the initial horror she brings so we can move towards an acceptance and hopefully a deeper understanding of this monstrous figure.

"The supernatural is difficult terrain; of its very nature, it resists discourse," Marina Warner acknowledges in her erudite study of the role of shapeshifting in Western perceptions of self and other. She states "The languages-and images-it uses can only remain in flux, constituting the reality of what they claim to describe or evoke, and are consequently shape- 
shifting themselves." ${ }^{38}$ I would argue that this holds true for the supernatural ground of the Philippines during the colonial Hispanic rule. Some scholars may object to the use of terms such as supernatural to a distinction between an observed world based on laws of nature and a range of phenomena seen to be a product of mysterious forces operating from beyond those laws. But by subsuming the shapeshifting manananggal into a seamless spectrum of "belief," we risk assuming that Filipinos somehow regarded these unsettling entities as a "normal" part of existence. On the other hand, by dismissing them as mere imaginary folklore, we run an equal risk of locking the precolonial/Hispanic Filipino into a rigid straitjacket of rationality.

The manananggal is a monster who will follow you out of the door and into the light of day: "These monsters ask us how we perceive the world, how we have misrepresented what we have attempted to place. They ask us to reevaluate our cultural assumptions about race, gender, sexuality, our perception of difference, our tolerance toward its expression. They ask us why we have created them." 39 


\section{Notes}

1. Maximo Ramos writes in Philippine Demonological Legends and their Cultural Bearings that there are other well-known terms for viscera-suckers: abat (Waray); boroka (Iloko, from Spanish word "bruja"); mangalok (Cuyonon); aswang na lupad (Bikol); naguneg (Iloko); laman luob (Tagalog) and kasudlan (West Visayan) (142). Viscera suckers are also found in Indonesia, Malaysia, Cambodia and Melanesia including the Trobriand Islands. They are known as tanggal in Indonesia and srei ap in Cambodia. Some viscera suckers are said to live in the jungle by day. They throw their arms over a branch, drape their hair over their faces, and sleep all day.

2. Refer to Judith Butler's Bodies that Matter, 1-57.

3. Although there are some identifying marks that set her apart, one can certainly identify a witch by day when one sees one's image inverted in the pupils of the asuang's eyes.

4. Meñez 86.

5. Meñez 86-87.

6. Jean-Michel Sallmann, "Witches." History of Women in the West: Renaissance and Enlightenment Paradoxes, vol. III, translated by Arthur Goldhammer, edited by Georges Duby and Michel Perrot, Harvard UP, 1995, 453.

7. Margaret Magat notes that a person can become an asuang in four ways: by personal desire, by receiving asuang powers from an asuang, by accidental contamination (eating food touched by an asuang); or by being born to an asuang. An individual who deliberately desires to transform into a viscera sucker must hold a "fertilized chicken egg against his/her belly and then tie it in place with a cloth around the body. After an unspecified time, the chicken from the egg passes into the stomach by a sort of osmosis. Then one becomes able to emit the sound characteristics" of the asuang (80). See "Balut: Duck Eggs and Their Role in Filipino Culture.” Western Folklore (Spring 2002) 61:1. 63-96. Another way to become asuang is by bringing two fertilized eggs to the cemetery after the Good Friday procession at night. There one should stand erect, gaze directly at the full moon without closing one's eyes, place and egg under one's armpit, and mumble certain words... when the egg disappears into the initiate's stomach, she becomes an asuang (see Ramos, Creatures of Lower Philippine Mythology, 122).

8. Julia Kristeva, Powers of Horror: An Essay on Abjection, Columbia UP, 1982, 1.

9. Meñez, 94.

10. Greg Bankoff, "Devils, Familiars and Spaniards: Spheres of Power and the Supernatural in the World of Seberina Candelaria and her Village in Early $19^{\text {th }}$ Century Philippines," Journal of Social History 33:1 (Fall 1999), 37-55. 
11. Bankoff relates the case as being about how power is conceptualized in a rural community in the late eighteenth- and earlynineteenth-century Philippines. Instead of overturning the ancient Philippine belief system, the forms and symbols of Christianity had been appropriated and merged within a pre-Hispanic mythology and tradition of chiefly female priestesses. The result is the formation of a hybrid cosmology. This cosmology was removed from the ideas of the Enlightenment than the Christianity of the early missionary fathers, who had at least shared with their converts more of a belief in the supernatural means of manipulating reality (49).

12. Catalonan is the Tagalog term for a local priestess.

13. The babaylan is a Visayan term for the local priestess who were mystical women and wielded social and spiritual power in pre-colonial Philippines.

14. Bankoff, 39 .

15. Bankoff, 40 .

16. Carolyn Brewer, Holy Confrontation: Religion, Gender and Sexuality in the Philippines, 1521-1685, St. Scholastica's College Institute of Women's Studies, 2001, 158.

17. Brewer, 158-159.

18. A demon familiar is also called a demon or imp. It generally follows the protagonist around and attacks every once in a while when it has been summoned.

19. Bankoff, 41.

20. Bankoff, 42 .

21. Bankoff, 42 .

22. Bankoff, 43.

23. Bankoff, 43.

24. These were recorded principally by Franciscan, Jesuit and Augustinian missionaries.

25. Meñez, 88.

26. Meñez, 92.

27. Bankoff, 40.

28. Meñez, 89.

29. Meñez, 90.

30. Anito is a collective term for the pre-Hispanic belief system in the Philippines that contains the spirits, including the household deities, deceased ancestors, nature spirits and diwatas (dryads). Ancient Filipinos kept statues that represented these spirits and asked them for guidance and protection. Much of this tradition has been Christianized and incorporated into what is now called folk Catholicism.

31. Meñez, 91.

32. Meñez, 91. 
33. Meñez, 91. Cited from Pedro Chirino's Relacion de las Islas Filipinas (1604) found in Blair and Robertson (1903-1909) 12: 167-324, 271-275.

34. Meñez, 89.

35. See Teresita Infante, The woman in early Philippines and among the cultural minorities. Unitas Publications, 1975; Amaryllis Torres, ed. The Filipino woman in focus: A book of readings. University of the Philippines Office of Research Coordination, 1995; and Carolyn Brewer, Holy Confrontation: Religion, Gender and Sexuality in the Philippines, 1521-1685, St. Scholastica's College Institute of Women's Studies, 2001.

36. Jeffrey Jerome Cohen, "Monster Culture (Seven Theses)," Monster Theory: Reading Culture, edited by Jeffrey J. Cohen, U of Minnesota P, 1996, 3-25.

37. Stacy Alaimo, "Discomforting Creatures: Monstrous Natures in Recent Films." Beyond Nature Writing: Expanding the Boundaries of Ecocriticism, edited by Karla Armbruster and Kathleen Wallace, UP of Virginia, 2001, 279-296, 294.

38. Marina Warner, Fantastic Metamorphoses, Other Worlds: ways of telling the self, Oxford UP, 2002, 159.

39. Cohen, 20. 


\section{Works Cited}

Alaimo, Stacy. "Discomforting Creatures: Monstrous Natures in Recent Films." Beyond Nature Writing: Expanding the Boundaries of Ecocriticism, edited by Karla Armbruster and Kathleen Wallace, UP of Virginia, 279-296, 294, 2001.

Bankoff, Greg. "Devils, Familiars and Spaniards: Spheres of Power and the Supernatural in the World of Seberina Candelaria and her Village in Early 19th Century Philippines." Journal of Social History 33:1 (Fall 1999). 37-55.

Brewer, Carolyn. Holy Confrontation: Religion, Gender and Sexuality in the Philippines, 152-1685. Manila: St. Scholastica's College Institute of Women’s Studies, 158, 2001.

Butler, Judith. Bodies that Matter: On the Discursive Limits of "Sex." London: Routledge, 1993.

Chirino, Pedro. Relacion de las Islas Filipinas (1604). In The Philippine Islands, 14931898, translated from the original, edited and annotated by Emma Helen Blair and James Alexander Robertson, with historical introduction and additional notes by Edward Gaylord Bourne. Cleveland, Ohio: A.H. Clark Company, 167-324. 271-275, 1903-1909

Cohen, Jeffrey Jerome. “Monster Culture (Seven Theses)," Monster Theory: Reading Culture, edited by Jeffrey J. Cohen, University of Minnesota Press, 3-25, 1996.

Eugenio, Damiana. “The Witch of Tawas.” The Legends: Philippine Folk Literature. Quezon City: University of the Philippines Press, 165-166, 2006.

Infante, Teresita. "The Woman in Early Philippines and Among the Cultural Minorities," edited by Amaryllis Torres, ed. The Filipino Woman in Docus: A Book of Readings. University of the Philippines Office of Research Coordination, 1995.

Kristeva, Julia. Powers of Horror: An Essay on Abjection. New York: Columbia University Press, 1982.

Magat, Margaret. "Balut: Duck Eggs and Their Role in Filipino Culture." Western Folklore (Spring 2002) 61:1. 63-96.

Meñez, Herminia. Explorations in Philippine Folklore. Quezon City: Ateneo de Manila University Press, 1996.

Ramos, Maximo. Philippine Demonological Legends and their Cultural Bearings. Quezon City: Phoenix Publishing House, 1990.

-----. Creatures of Philippine lower mythology. Quezon City: University of the Philippines Press, 1971.

Sallman, Jean-Michel. "Witches." History of Women in the West: Renaissance and Enlightenment Paradoxes, vol. III, translated by Arthur Goldhammer, edited by Georges Duby and Michel Perrot. Harvard UP, 453, 1995.

Warner, Marina. Fantastic Metamorphoses, Other Worlds: ways of telling the self. Oxford UP, 159, 2002. 